Pak. J. Agri., Agril. Engg., Vet. Sci., 2021, 37 (1): 1-10

ISSN: 1023-1072 (Print), ISSN: 2663-7863 (Online)

https://doi.org/10.47432/2020.37.1.1

\title{
ACHIEVING SUSTAINABLE RICE PRODUCTION WITH THE APPLICATION OF SUGARCANE INDUSTRIAL BY-PRODUCTS
}

\author{
Q. A. Raza ${ }^{1}$, M. A. Bashir ${ }^{1}$, A. Rehim ${ }^{1}$, M. Zafar-ul-Hye ${ }^{1}$ and Z. H. Tarar ${ }^{2}$ \\ ${ }^{1}$ Department of Soil Science, Faculty of Agricultural Sciences and Technology, \\ Bahauddin Zakariya University, Multan, Pakistan \\ ${ }^{2}$ Soil and Water Testing Laboratory, Mandi Bahauddin, Punjab, Pakistan
}

\begin{abstract}
Sugarcane industries generate a variety of by-products, which create disposal and environmental problems. The aim of current study was to find out the ways for utilization of these by-products in rice production. To elucidate this, a field trial was conducted at the research area $\left(30.2^{\circ} \mathrm{E} ; 71.5 \mathrm{~N}^{\circ}\right)$ of Bahauddin Zakariya University Multan, Pakistan. The calcareous soil with high $\mathrm{pH}(8.6)$ and low organic matter $(0.5 \%)$ was used with following treatments: no input control $(\mathrm{CK})$, only chemical fertilizer, nitrogen, phosphorus and potassium (NPK; CF), NPK+ Sugarcane Bagasse (SB), NPK+ Press Mud (PM), NPK+ Sugarcane Vinasse (SV), NPK+SB+PM (SB+PM), NPK+SB+SV (SB+SV), $\mathrm{NPK}+\mathrm{PM}+\mathrm{SV}(\mathrm{PM}+\mathrm{SV}), \mathrm{NPK}+\mathrm{SB}+\mathrm{PM}+\mathrm{SV}(\mathrm{SB}+\mathrm{PM}+\mathrm{SV})$. The results showed that SB significantly increased the plant height (16.3\%), panicle length (9.3\%), paddy yield (213.1\%), and straw yield (189. $9 \%)$. Nutrient uptake was also improved, SB enhanced TN $(324.6 \%)$, while the SB+PM increased the total phosphorus $(318.2 \%)$, and total potassium $(163.7 \%)$ contents in grains. Likewise, agronomic nutrient use efficiency was enhanced in SB treatment for $\mathrm{N}(274.2 \%), \mathrm{P}(81.4 \%)$, and $\mathrm{K}(378.5 \%)$. Maximum net profit and benefit-cost ratio was observed in SB (93925 rupees; 0.54$)$, followed by PM (91150; 0.53), SB+PM (85338; 0.51), and minimum was in control (12400; 0.22), respectively. The study concludes, application of organic by-products ( $\mathrm{SB}+\mathrm{PM})$ can increase rice productivity and farm income with environmental safety.
\end{abstract}

Keywords: by-products, organic inputs, rice, sugarcane

\section{INTRODUCTION ${ }^{1}$}

Rice is the staple food of about $50 \%$ population worldwide and is a major cash crop after wheat and cotton in Pakistan (Bashir et al., 2020). In 2018-2019, its cultivation area in Pakistan was 2,810 thousand hectares and production was 7202 million tonnes, which contributes about $0.6 \%$ in GDP (Pakistan Bureau of Statistics, 2019). It plays a vital role in uplifting the agricultural economy of the country and the living standard of the farming community (Hussain, 2013). To fulfil the high food demand due to the increasing population, the use of chemical fertilization has achieved high productivity. However, continuous application of these chemicals without organic residual incorporation resulted into deterioration the soil fertility and carbon sequestration ( $\mathrm{Ku}$ et al., 2019).

*Corresponding author: abdur.rehim@bzu.edu.pk
Sugarcane (Saccharum officinarum L.) is one of the major food and cash crops cultivated globally due to its higher productivity (Payá et al., 2018). In 2014, sugarcane productivity in Africa, America, and Asia was about 1.48, 14.18 , and 11.03 million hectares whereas sugar production was about 95.53, 1007.71, and 748.41 million tons respectively (Gonfa et al., 2018). Moreover, in the same year sugarcane productivity was 81.102 million tons in Pakistan. Besides, sugarcane processing industries also produce alcohol and some by-products that have serious concerns about safe disposal and, are causing harmful impacts on environmental health (Yang et al., 2013). The crushing and juice extraction from the canes results in the production of sugarcane bagasse (SB), which is a fibrous material (Pandey et al., 2000). Press mud (PM) is mainly produced released after the filtration process of sugarcane juice. Crushing of $100 \mathrm{~kg}$ sugarcane results in $3 \mathrm{~kg}$ of PM 
production as a by-product (Kalaivanan and Omar Hattab, 2016). Ethanol production from cane industries gives rise to another by-product known as sugarcane vinasse (SV), processing of 1-liter ethanol produces about 10-15 liters of SV (Da Silva et al., 2014).

Utilization of these by-products in the agricultural sector as an organic source of fertilization can help to reduce chemical fertilization, resolve to dispose of issues of by-products and improve the farmer's income (Sarwar et al., 2008; Zhang et al., 2018). Integrated use of organic and inorganic fertilizers enhances sustainable agricultural production, maintains soil health and fertility, and environmental safety (Chen et al., 2017).

In addition, the application of SV and PM acts as substitutes to reduce chemical fertilization, improve sugarcane productivity, soil health, and considered as environmentally safe disposal (Yang et al., 2013). PM can reduce $20 \%$ of chemical fertilization without affecting the yield (Kalaivanan and Omar Hattab, 2016). Integrated use of chemical fertilizers and PM (75:25 ratio) has a significantly positive effect on maize productivity andimproves nitrogen (N) uptake, (Wei et al., 2017). It is revealed that the use of organic and inorganic fertilizers improves crop yield in short-term as well as soil organic matter in long-term (Wei et al., 2016). The application of PM attributes to rapid $\mathrm{N}$ mineralization and sustained $\mathrm{N}$ supply for high grain yield as it meets the long-term requirement of rice crop (Kalaivanan and Omar Hattab, 2016). There is no direct information of these byproducts to be used as a combined fertilization source with chemical fertilizers to influence rice productivity, their influence on-field water nutrients concentration. Whereas, application of composted PM has improved the rice production (Kalaivanan and Omar Hattab, 2016). Sugarcane bagasse is a cheap organic source of fertilizer but few studies is reported. The longterm effects of organic inputs on crop production are also a research gap. In the current study, sugarcane industrial by-products are used with a combination of chemical fertilization to find their impact on rice productivity. The current study was conducted to find the safe disposal methods for wastes and utilize the locally produced wastes as agricultural inputs to reduce chemical fertilization cost. The main objectives of this study were to utilize waste products of sugarcane industries for agricultural production, to find out the safe way to dispose-off agri-based industrial by-products, and reduce the cost of chemical fertilization to earn more capita for agricultural community.

\section{MATERIALS AND METHODS Experimental site}

To ascertain the effects of sugarcane byproducts on rice production, a field experiment was conducted at the research area $\left(30.2^{0} \mathrm{E}\right.$, $71.5^{\circ} \mathrm{N}$ ) of the Department of Soil Science, Faculty of Agricultural Sciences and Technology, Bahauddin Zakariya University, Multan, Pakistan. The city is known as the city of saints and is located at the bank of river Chenab and agricultural land gets irrigated from its tributaries. The climate of the area is semi-arid with very hot summers and mild winters, the mean annual temperature is $25.6^{\circ} \mathrm{C}$, and the mean annual precipitation is 186 millimetres. The irrigation water used during the study had $\mathrm{pH}$ (8.07), electrical conductivity (EC; 1.09 dS $\left.\mathrm{m}^{-1}\right)$, nitrate $\left(2.2 \mathrm{mgL}^{-1}\right)$, and available $P$ $\left(1.76 \mathrm{mgL}^{-1}\right)$. Due to the high $\mathrm{EC}$ of irrigation water, increased EC was observed in postharvest soil samples. The physico-chemical properties of the soil used in the experiment are given in (Table 1).

\section{Experimental design}

The soil was deeply ploughed and sub-divided into twenty-seven plots with $12 \mathrm{~m}^{2}$ size. Sugarcane by-products (organic natured) i.e. SB, PM, and SV along with NPK (110:70:60 $\mathrm{kgha}^{-1}$ ) chemical fertilizers were applied. The dose of organic compounds was at par with the recommended dose of organic compounds application 1.25 tons' ha $^{-1}$ (Kalaivanan and Omar Hattab, 2016). With single organic input the dose was $100 \%$, whereas $50 \%$ and $33.3 \%$ was used when applied in combination. The organic amendments used in the experiment were analysed for NPK contents (Table 2). The experiment had nine treatments with three replications in a Randomized Complete Block Design. The tested treatments were: no input control (CK), only NPK (CF), NPK+ Sugarcane Bagasse (SB), NPK+ Press Mud (PM), NPK+ Sugarcane Vinasse (SV), NPK+SB+PM (SB+PM), NPK+SB+SV (SB+SV), NPK+PM+SV $(\mathrm{PM}+\mathrm{SV}), \mathrm{NPK}+\mathrm{SB}+\mathrm{PM}+\mathrm{SV}(\mathrm{SB}+\mathrm{PM}+\mathrm{SV})$. The total input dose (1.25 tons $\mathrm{ha}^{-1}$ ) for organic substances was remained the same to maintain the total input. The field was saturated with irrigation water for three days. Rice (Oryza sativa L. CV. Kainat) seedlings ( 25 days old) were transplanted on the third day with plant $x$ row spacing of $10 \times 15 \mathrm{~cm}$. 
Table 1. Physico-chemical properties of soil

\begin{tabular}{|l|l|l|l|l|}
\hline Parameters & Unit & Value & Interpretation & References \\
\hline $\mathrm{pHs}$ & - & $8.6 \pm 0.1$ & Alkaline & $\mathrm{pHs}$ \\
\hline $\mathrm{ECe}$ & $\mathrm{dSm}^{-1}$ & $0.8 \pm 0.1$ & Alkaline & $\mathrm{pHs}$ \\
\hline Texture & & Loam & & $\begin{array}{l}\text { Hydrometer } \\
\text { method }\end{array}$ \\
\hline $\begin{array}{l}\text { Organic } \\
\text { Matter }\end{array}$ & $\%$ & $0.5 \pm 0.1$ & Low & $\begin{array}{l}\text { (Walkley, } \\
1947)\end{array}$ \\
\hline $\begin{array}{l}\text { Total } \\
\text { Nitrogen }\end{array}$ & $\mathrm{mg} / \mathrm{kg}$ & $225 \pm 0.2$ & Low & $\begin{array}{l}\text { (Jackson, } \\
1960)\end{array}$ \\
\hline $\begin{array}{l}\text { Olsen- } \\
\text { Phosphorus }\end{array}$ & $\mathrm{mg} / \mathrm{kg}$ & $7.9 \pm 0.2$ & Medium & $\begin{array}{l}\text { (Olsen et al., } \\
1950)\end{array}$ \\
\hline $\begin{array}{l}\text { Available } \\
\text { Potassium }\end{array}$ & $\mathrm{mg} / \mathrm{kg}$ & $29.7 \pm 0.5$ & Low & $\begin{array}{l}\text { (Richards, } \\
1954)\end{array}$ \\
\hline
\end{tabular}

All values are given as Means \pm Standard deviations

All the treatments received an equal amount of fertilizers except CK (no fertilizer application). Fertilization was done in the form of Urea for N, di-ammonium phosphate (DAP) for $\mathrm{P}$ and sulphate of potash (SOP) for K. Urea was applied in two splits, half before rice transplantation and another half after 30 days of transplantation (Bashir et al., 2021). Insecticide and pesticide were not used, weeds were removed manually, and the crop was harvested on maturity.

\section{Rice yield and productivity}

At maturity, five rice plants were collected randomly from each plot and plant height, the number of productive tillers per hill were noted. Three plants from each plot were harvested for the determination of filled grains panicle ${ }^{-1}$, shrivelled grains panicle ${ }^{-1}$, seed setting percentage, and the panicle length. Rice was harvested from one square meter area from each plot manually. The paddy and straw weight were measured for the determination of grain and biomass yield (tons ha ${ }^{-1}$ ). Thousand grains weight $(\mathrm{g})$ was obtained by counting 1000 grains manually and then weighed.

\section{Nutrient uptake}

The paddy grain and straw samples from each plot were ground, digested, and filtered. Total $\mathrm{N}$ (TN), Total P (TP) and Total K (TK; $\mathrm{g} \mathrm{kg}^{-1}$ ) concentration was determined by Kjeldahl $\mathrm{N}$ determination (Kjeldahl, 1883), TP with a spectrophotometer (McGeorge, 1954) and TK with a flame photometer (Reitemeier, 1963). Analyses were followed according to the local environmental and lab condition (Bashir et al., 2019). Nutrient uptake by grain and straw was determined by multiplying grain/straw nutrient concentration $\left(\mathrm{g} \mathrm{kg}^{-1}\right)$ with grain/straw yield divided by 1000 .

\section{Nutrient use efficiency}

Nutrient use efficiency (\%) was measured by dividing each nutrient acquired with nutrient applied. Nutrients use efficiency for N, P, and K use were measured. Internal N-efficiency (INE; $\mathrm{kg} \mathrm{kg}^{-1}$ ) was estimated by dividing plant biomass with plant $\mathrm{N}$. Harvest Index (HI; \%) was measured by dividing grain yield with biological yield. Nitrogen Partial Factor Productivity (NPFP; $\mathrm{kg}_{\text {grain }} \mathrm{kg}^{-1} \mathrm{~N}$ ) was calculated by dividing grain yield with applied $\mathrm{N}$ in each plot.

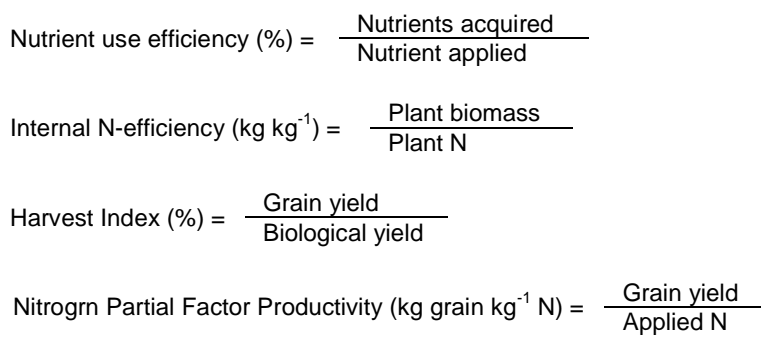

Measurement of nitrate and phosphorus infield water

The water samples from each plot were collected at different intervals $(1,3,5,10,15$, $25,38,53,68$, and 89 days of fertilization) during the experiment. Water samples were passed through filter paper to remove impurities (such as soil particles, phytoplankton). The water samples were analyzed for nitrate (Cataldo et al., 1975) and available-P (Olsen et al., 1954).

\section{Economic analysis}

The total cost of the experiment was obtained by adding all the expenditures of field operations (labor, rice seedling, fertilizer, organics, transport, and irrigation). Farm income was calculated with the earnings from rice according to the local market. The benefit-cost ratio (BCR) was calculated using the given expression.

$\mathrm{BCR}=\frac{\text { Total Net Income }}{\text { Total Expenditure }}$

\section{Statistical analysis}

All the data given in tables and graphs are presented as means \pm standard deviations for the three replicates. General Linear Model (GLM) was used for one-way analysis of variance (ANOVA) with IBM SPSS $\AA$ (version 21 ), and the significant difference was determined with Least Significant Difference (LSD) at $P \leq 0.05$ using Duncan multiple comparison test. Data processing and graph preparation were done by using Microsoft Excel 2016. 


\section{RESULTS}

\section{Rice yield and productivity}

The integrated use of industrial sugarcane byproducts improved the agronomic and productive traits of rice crop significantly (Table 3 ). The plant height was significantly improved in SB (16.3\%) and PM (15.8\%), followed by SB+PM (10.6\%) as compared to the CK. The number of productive tillers was significantly increased in SB+SV (104.4\%), SB (104.4\%) and PM (101.1\%). In addition, panicle length was maximum in SB $(24.70 \mathrm{~cm})$ and SV $(24.51 \mathrm{~cm})$, followed by SB+PM $(23.77 \mathrm{~cm})$ and the minimum was in CF $(21.49 \mathrm{~cm})$. The number of filled grains panicle ${ }^{-1}$ was significantly improved in SV (32.3\%) in comparison with CK (Figure 1). The number of shrivelled grains panicle ${ }^{-1}$ was significantly reduced in SB $(-31.0 \%)$ as compared to $\mathrm{CK}$.

The seed setting percentage was significantly enhanced in SB+PM (16.1\%) and PM (15.3\%) as compared to CK. Results revealed that 1000 -grain weight was significantly high in PM+SV (29.6 g). The straw yield was improved significantly in SB (189.9\%) as compared to the CK treatment. Paddy yield is an important parameter for rice productivity; it was significantly enhanced in SB (213.1\%) and PM (208.8\%).

\section{Nutrient uptake}

Grain N uptake was significantly enhanced in SB $(324.6 \%)$ and SB+PM (308.8\%), followed by PM $(212.3 \%)$ as compared to CK. Grain P (318.2\%) and $\mathrm{K}$ uptake (163.7\%) was also improved significantly in SB+PM compared to CK. The straw $\mathrm{N}$ uptake was significantly enhanced in SB+PM (279.2\%), SB (233.3\%), and PM $(233.3 \%)$ as compared to the CK. Straw P uptake was also significantly enhanced in $\mathrm{SB}(400 \%)$. Straw $\mathrm{K}$ uptake was significantly increased in SB (223\%) (Table 4).

\section{Nutrient use efficiency}

Nitrogen use efficiency was significantly increased in SB (274.2\%) and SB+PM (274.1\%), followed by PM (196.7\%). Phosphorus use efficiency was significantly enhanced in SB (81.4\%). Potassium use efficiency also improved significantly by the application of SB (378.5\%), followed by SV (320.2\%) and SB+PM+SV $(306.6 \%)$ as compared to CK. Internal Nefficiency also increased significantly in $\mathrm{SB}+\mathrm{PM}$ $(152.1 \%)$, followed by SV $(93.7 \%)$. Harvest Index was improved in SB+SV (31.1\%) and it was minimum in CF. Nitrogen Partial Factor
Productivity was significantly enhanced in SB $(213.8 \%)$ and PM (209.5\%) as compared to CK (Figure 2).

\section{Measurement of nitrate and available phosphorus in-field water}

Results revealed that integrated use of organic by-products and inorganic fertilizer had reduced the nutrient losses in water thus reducing the environmental pollution. Nitrate concentration in water was high at early rice growth in CF compared to SB, SV, SB+SV, and other treatments. The concentration was decreased in mid-stages in all treatments and but in lateral stages of the rice crop was increased in SB, $\mathrm{SB}+\mathrm{PM}, \mathrm{SB}+\mathrm{SV}$ compared to control, and $\mathrm{CF}$ (Figure 3a). Integrated fertilization management increased the available $P$ concentration in surface water during early stages especially in $\mathrm{SB}+\mathrm{PM}, \mathrm{SB}+\mathrm{SV}, \mathrm{PM}$, and other treatments, but the concentration was low in $\mathrm{CK}$ treatment. Moreover, at mid-stages $\mathrm{SB}+\mathrm{SV}$ and $\mathrm{SB}+\mathrm{PM}$ showed higher available $P$ concentration. At lateral stages, all treatment increased the $P$ concentration in-field water compared with CK (Figure 3b).

\section{Economic analysis}

The total cost was highest in SV (167350 PKR $\left.\mathrm{ha}^{-1}\right)$ due to the high cost of organics $(93750$ PKR ha $\left.{ }^{-1}\right)$. Followed by PM+SV (124100 PKR $\left.\mathrm{ha}^{-1}\right)$ and SB+SV (123912 PKR ha $\left.{ }^{-1}\right)$. The net income was highest in SB (93925 PKR ha-1) followed by PM (91150 PKR ha ${ }^{-1}$ ) and SB+PM (85338 PKR ha ${ }^{-1}$ ). The cost-benefit ratio was highest in SB (0.54), followed by PM (0.53) and SB+PM (0.51) (Table 5).

\section{DISCUSSION}

The results revealed that the rice productivity increases with the combined application of chemical fertilizers and organic amendments (Table 2). This improvement might be associated with nutrient availability through organics ((da Silva et al., 2014; Soni et al., 2014). Besides, the organics might be the source of slow nutrient release that optimizes their availability throughout the rice growth period ((Kalaivanan and Omar Hattab, 2016). The number of filled grains panicle ${ }^{-1}$ was also increased with co-fertilization of NPK with organic amendments. This leads to better soil fertility and improved crop yields. The shrivelled grains panicle ${ }^{-1}$ was reduced in SB, PM, and $\mathrm{SB}+\mathrm{PM}$ treatments. These organic inputs also significantly increased seed setting percentages. 
The treatments receiving fertilizers with byproducts gave higher straw and grain yields (Figure 1). It was enhanced significantly in SB treatment due to its wider $\mathrm{C} / \mathrm{N}$ ratio that improved the available $\mathrm{N}$ and $\mathrm{P}$ in surface water and their uptake at growth stages compared to the $\mathrm{CK}$ and $\mathrm{CF}$. Wider $\mathrm{C} / \mathrm{N}$ ratio of SB tend to enhance long-term and continuous $\mathrm{N}$ availability throughout the productivity period (Prado et al., 2013). Besides, the use of organic amendments increases the soil organic carbon accumulation which is linearly correlated with the enhances rice yield (Zhang et al., 2018). Plant nutrient uptake was significantly affected by the application of organic wastes. It was significantly increased with SB and SB+PM as compared to other treatments (Table 4). The improved yield was also associated with high nutrient uptake (Gonfa et al., 2018; Rehman, 2019).

Additionally, it might be attributed to improvement in soil physical and biological properties which enhanced plant nutrient availability (Bahadur et al., 2013). The use of organic amendments reduces the soil $\mathrm{pH}$, thus increases nutrient availability ((Mahmood et al., 2017). Moreover, organic amendments improve nutrient availability, enhance $\mathrm{N}$ uptake, and modulate $\mathrm{N}$ by adjusting the retention and release process (Zhang et al., 2018). The use of organic inputs favors the $\mathrm{N}$ immobilization at initial growth and subsequent gradual remineralization and improves the $\mathrm{N}$ absorption by plants (Zhang et al., 2018).

Table 2. Nutritional (NPK) contents of sugarcane byproducts

\begin{tabular}{|l|l|l|l|}
\hline Contents & $\begin{array}{l}\text { Sugarcane } \\
\text { Bagasse }\end{array}$ & $\begin{array}{l}\text { Press } \\
\text { Mud }\end{array}$ & $\begin{array}{l}\text { Sugarcane } \\
\text { Vinasse }\end{array}$ \\
\hline Nitrogen (\%) & $0.90 \pm 0.08$ & $1.20 \pm 0.17$ & $1.50 \pm 0.11$ \\
\hline Phosphorus (\%) & $0.04 \pm 0.01$ & $0.64 \pm 0.12$ & $0.07 \pm 0.02$ \\
\hline Potassium (\%) & $0.03 \pm 0.01$ & $0.14 \pm 0.04$ & $2.50 \pm 0.13$ \\
\hline
\end{tabular}

Note: All values are given as Means \pm Standard deviations

Table 3. Agronomic traits influenced with addition of by-products

\begin{tabular}{|l|l|l|l|}
\hline Treatment & $\begin{array}{l}\text { Plant height } \\
(\mathbf{c m})\end{array}$ & $\begin{array}{l}\text { Number of } \\
\text { Productive } \\
\text { tillers }\end{array}$ & $\begin{array}{l}\text { Panicle } \\
\text { length }(\mathbf{c m})\end{array}$ \\
\hline CK & $84.0 \pm 2.3^{\mathrm{d}}$ & $9.1 \pm 1.2^{\mathrm{a}}$ & $22.5 \pm 2.7^{\mathrm{abc}}$ \\
\hline $\mathrm{CF}$ & $88.2 \pm 0.8^{\mathrm{c}}$ & $16.3 \pm 2.2^{\mathrm{ab}}$ & $21.1 \pm 1.0^{\mathrm{c}}$ \\
\hline SB & $97.7 \pm 2.6^{\mathrm{a}}$ & $18.6 \pm 2.3^{\mathrm{a}}$ & $24.6 \pm 0.5^{\mathrm{a}}$ \\
\hline $\mathrm{PM}$ & $97.3 \pm 2.0^{\mathrm{a}}$ & $18.3 \pm 1.3^{\mathrm{a}}$ & $23.1 \pm 0.6^{\mathrm{abc}}$ \\
\hline SV & $92.4 \pm 2.6^{\mathrm{b}}$ & $15.0 \pm 3.0^{\mathrm{bc}}$ & $24.1 \pm 1.1^{\mathrm{a}}$ \\
\hline $\mathrm{SB}+\mathrm{PM}$ & $92.9 \pm 2.7^{\mathrm{b}}$ & $16.2 \pm 0.4^{\mathrm{ab}}$ & $23.5 \pm 0.9^{\mathrm{ab}}$ \\
\hline $\mathrm{SB}+\mathrm{SV}$ & $92.6 \pm 2.5^{\mathrm{b}}$ & $18.6 \pm 1.1^{\mathrm{a}}$ & $22.6 \pm 1.7^{\mathrm{abc}}$ \\
\hline $\mathrm{PM}+\mathrm{SV}$ & $89.4 \pm 1.4^{\mathrm{bc}}$ & $17.1 \pm 1.5^{\mathrm{ab}}$ & $21.5 \pm 0.2^{\mathrm{bc}}$ \\
\hline SB+PM+SV & $91.4 \pm 1.0^{\mathrm{bc}}$ & $12.3 \pm 0.6^{\mathrm{c}}$ & $23.0 \pm 0.5^{\mathrm{abc}}$ \\
\hline
\end{tabular}

Note: $C K$ is No input control, CF is only NPK, SB is NPK+SB, PM is $\mathrm{NPK}+\mathrm{PM}, \mathrm{SV}$ is $\mathrm{NPK}+\mathrm{SV}, \mathrm{SB}+\mathrm{PM}$ is $\mathrm{NPK}+\mathrm{SB}+\mathrm{PM}, \mathrm{SB}+\mathrm{SV}$ is $\mathrm{NPK}+\mathrm{SB}+\mathrm{SV}, \quad \mathrm{PM}+\mathrm{SV}$ is $\mathrm{NPK}+\mathrm{PM}+\mathrm{SV}, \quad \mathrm{SB}+\mathrm{PM}+\mathrm{SV}$ is $\mathrm{NPK}+\mathrm{SB}+\mathrm{PM}+\mathrm{SV}$. All values are given as Means \pm Standard deviations $(\mathrm{LSD}=0.05)$.

Table 4. Influence of organic amendments on the TN, TP and TK uptake in rice straw and grain

\begin{tabular}{|c|c|c|c|c|c|c|}
\hline \multirow[t]{3}{*}{ Treatment } & \multicolumn{3}{|c|}{ Grain } & \multicolumn{3}{|c|}{ Straw } \\
\hline & TN & TP & TK & TN & TP & TK \\
\hline & \multicolumn{3}{|l|}{$\left(\mathrm{kg} \mathrm{ha}^{-1}\right)$} & \multicolumn{3}{|l|}{$\left(\mathrm{kg} \mathrm{ha}^{-1}\right)$} \\
\hline CK & $5.7 \pm 0.2^{f}$ & $1.1 \pm 0.4^{\mathrm{d}}$ & $2.2 \pm 0.7^{e}$ & $2.4 \pm 0.5^{\mathrm{e}}$ & $1.3 \pm 0.3^{\mathrm{e}}$ & $6.1 \pm 1.1^{g}$ \\
\hline $\mathrm{CF}$ & $7.7 \pm 0.2^{\mathrm{e}}$ & $1.9 \pm 0.1^{\mathrm{cd}}$ & $2.7 \pm 0.1^{\mathrm{de}}$ & $6.5 \pm 0.9^{b}$ & $3.2 \pm 0.6^{\mathrm{d}}$ & $11.8 \pm 1.3^{\mathrm{ef}}$ \\
\hline SB & $24.2 \pm 0.9^{a}$ & $3.8 \pm 0.7^{\mathrm{ab}}$ & $4.9 \pm 1.1^{\mathrm{abc}}$ & $8.0 \pm 0.2^{\mathrm{a}}$ & $6.5 \pm 0.9^{a}$ & $19.7 \pm 1.2^{\mathrm{a}}$ \\
\hline PM & $17.8 \pm 0.5^{b}$ & $3.9 \pm 0.4^{\mathrm{ab}}$ & $5.2 \pm 0.4^{\mathrm{ab}}$ & $8.0 \pm 0.6^{\mathrm{a}}$ & $6.0 \pm 0.4^{\mathrm{ab}}$ & $14.4 \pm 0.9^{\text {cd }}$ \\
\hline SV & $15.9 \pm 0.8^{c}$ & $3.8 \pm 0.5^{\mathrm{ab}}$ & $5.2 \pm 0.4^{\mathrm{ab}}$ & $6.8 \pm 0.4^{b}$ & $4.8 \pm 0.5^{\mathrm{bc}}$ & $17.3 \pm 1.0^{\mathrm{ab}}$ \\
\hline $\mathrm{SB}+\mathrm{PM}$ & $23.3 \pm 0.6^{a}$ & $4.6 \pm 0.5^{\mathrm{a}}$ & $5.8 \pm 0.7^{\mathrm{a}}$ & $9.1 \pm 0.3^{\mathrm{a}}$ & $4.7 \pm 0.4^{\mathrm{C}}$ & $15.3 \pm 0.6^{\mathrm{bc}}$ \\
\hline $\mathrm{SB}+\mathrm{SV}$ & $13.5 \pm 0.5^{\mathrm{d}}$ & $3.0 \pm 0.5^{b}$ & $4.1 \pm 0.5^{\mathrm{bc}}$ & $4.3 \pm 0.4^{\mathrm{d}}$ & $4.8 \pm 0.5^{C}$ & $12.6 \pm 1.4^{\mathrm{de}}$ \\
\hline $\mathrm{PM}+\mathrm{SV}$ & $12.9 \pm 0.6^{\mathrm{d}}$ & $2.9 \pm 0.4^{\mathrm{bc}}$ & $3.7 \pm 0.3^{\mathrm{cd}}$ & $5.3 \pm 0.3^{\mathrm{cd}}$ & $4.1 \pm 0.4^{\mathrm{cd}}$ & $9.8 \pm 0.7^{\dagger}$ \\
\hline $\mathrm{SB}+\mathrm{PM}+\mathrm{SV}$ & $14.1 \pm 0.5^{\mathrm{d}}$ & $3.7 \pm 0.4^{a b}$ & $4.5 \pm 0.3^{\mathrm{abc}}$ & $6.1 \pm 0.5^{\mathrm{bc}}$ & $4.6 \pm 0.3^{c}$ & $17.2 \pm 1.4^{\mathrm{ab}}$ \\
\hline
\end{tabular}

Note: $C K$ is No input control, $C F$ is only NPK, $S B$ is NPK+ SB, PM is NPK+ PM, SV is NPK+SV, $S B+P M$ is NPK+SB +PM, SB+SV is NPK+SB+SV, $P M+S V$ is $\mathrm{NPK}+\mathrm{PM}+\mathrm{SV}, \mathrm{SB}+\mathrm{PM}+\mathrm{SV}$ is $\mathrm{NPK}+\mathrm{SB}+\mathrm{PM}+\mathrm{SV}$. TN is total nitrogen, TP is total phosphorus, and TK is total potassium. All values are given as Means \pm Standard deviations $(L S D=0.05)$

Table 5. Economic Analysis of sugar industry by-products in a field experiment

\begin{tabular}{|l|l|l|l|l|l|l|l|l|l|l|}
\hline Treatment & & CK & CF & SB & PM & SV & SB+PM & SB+SV & SV+PM & SB+PM+SV \\
\hline COST & Labor+Irrigation & 25000 & 25000 & 30000 & 30000 & 30000 & 30000 & 30000 & 30000 & 30000 \\
\hline & Rice Seedling & 18600 & 18600 & 18600 & 18600 & 18600 & 18600 & 18600 & 18600 & 18600 \\
\hline & Fertilizer & 0 & 25000 & 25000 & 25000 & 25000 & 25000 & 25000 & 25000 & 25000 \\
\hline & Organics & 0 & 0 & 7875 & 8250 & 93750 & 7062 & 50312 & 50500 & 35954 \\
\hline Total & & 43600 & 68600 & 81475 & 81850 & 167350 & 80662 & 123912 & 124100 & 109554 \\
\hline Income & Rice & 56000 & 92800 & 175400 & 173000 & 160700 & 166000 & 140700 & 129000 & 141400 \\
\hline Net Income & & 12400 & 24200 & 93925 & 91150 & -6650 & 85338 & 16788 & 4900 & 31846 \\
\hline Benefit-Cost Ratio & & 0.22 & 0.26 & 0.54 & 0.53 & -0.04 & 0.51 & 0.12 & 0.04 & 0.23 \\
\hline
\end{tabular}

Note: All the prices are given in PKR ha ${ }^{-1}(156 \mathrm{PKR}=1 \mathrm{USD})$. CK is No input control, CF is only $\mathrm{NPK}, \mathrm{SB}$ is $\mathrm{NPK}+\mathrm{SB}, \mathrm{PM}$ is $\mathrm{NPK}+\mathrm{PM}, \mathrm{SV}$ is NPK+SV, $\mathrm{SB}+\mathrm{PM}$ is $\mathrm{NPK}+\mathrm{SB}+\mathrm{PM}, \mathrm{SB}+\mathrm{SV}$ is $\mathrm{NPK}+\mathrm{SB}+\mathrm{SV}, \mathrm{PM}+\mathrm{SV}$ is $\mathrm{NPK}+\mathrm{PM}+\mathrm{SV}, \mathrm{SB}+\mathrm{PM}+\mathrm{SV}$ is $\mathrm{NPK}+\mathrm{SB}+\mathrm{PM}+\mathrm{SV}$. 

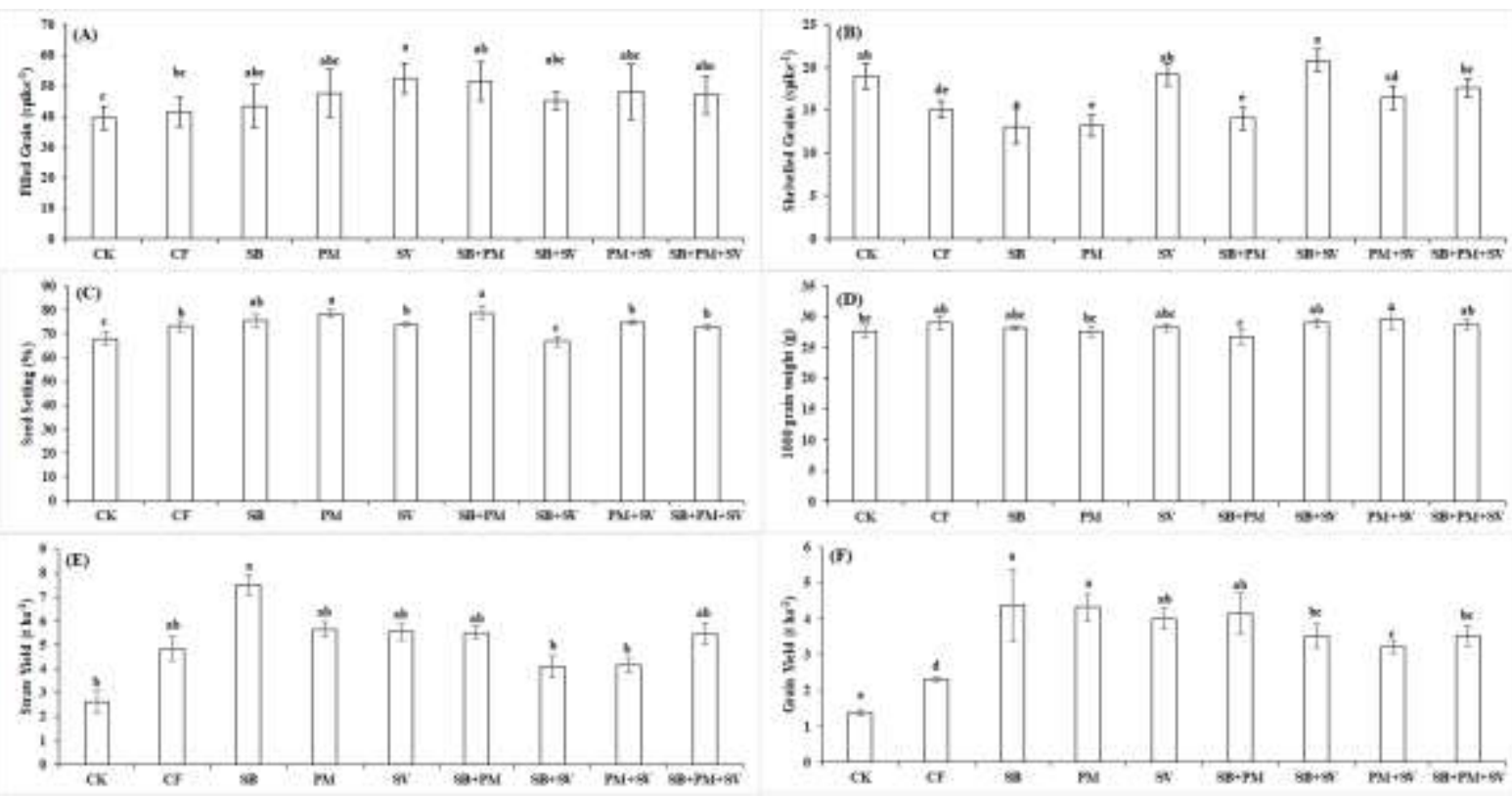

Figure 1. Rice productivity and yield parameters $(A)$ filled grains panicle ${ }^{-1}(B)$ shriveled grains panicle ${ }^{-1}(C)$ seed setting percentage (D) 1000-grain weight $(E)$ straw yield (F)grain yield. All the values are given as means $\pm S$.D.
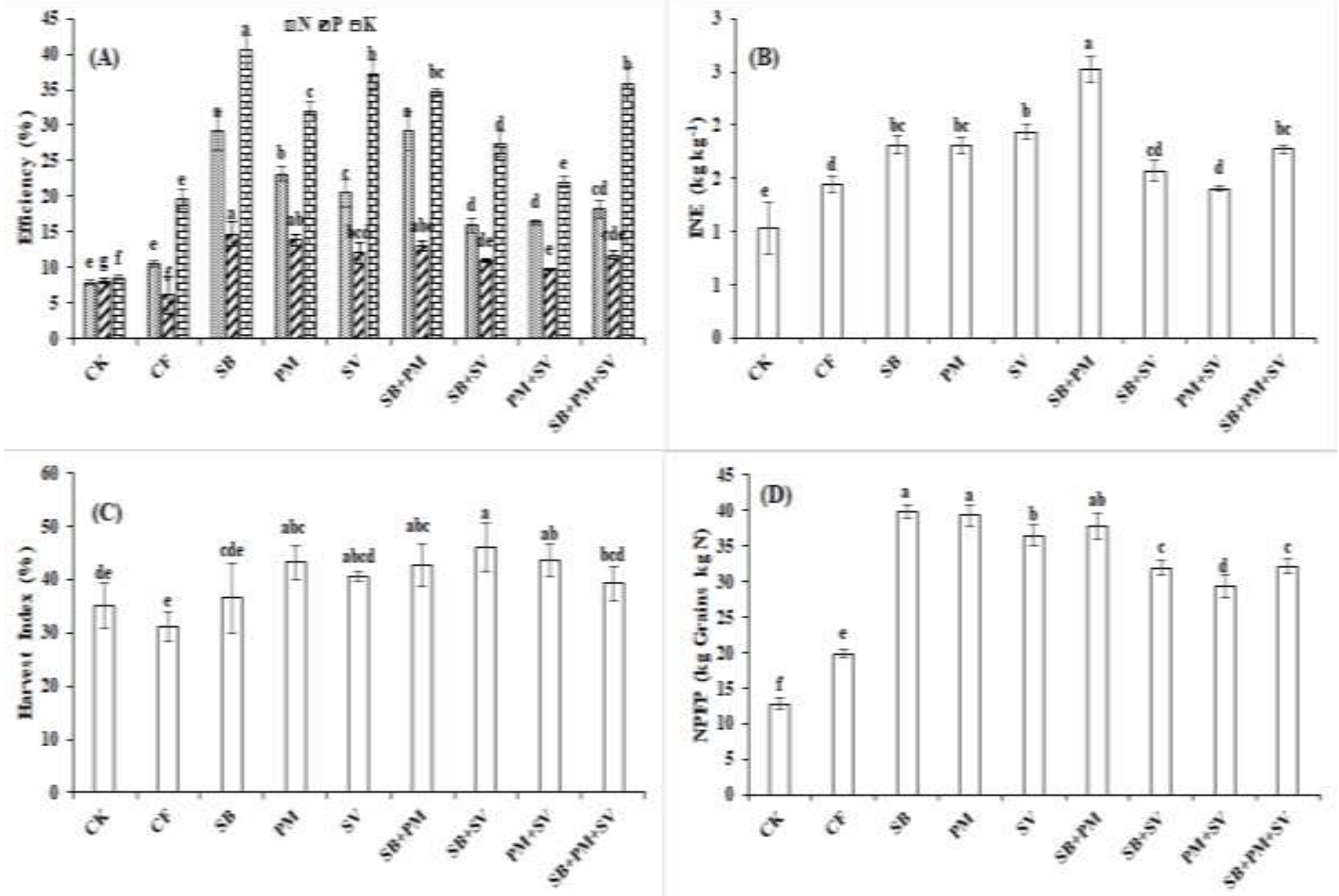

Figure 2. Nutrient use efficiency (A) nutrient use efficiency (B) internal nitrogen use efficiency (INE) (C) harvest Index $(\mathrm{HI})(\mathrm{D})$ nitrogen partial factor productivity (NPFP). All the values are given as means \pm S.D. 

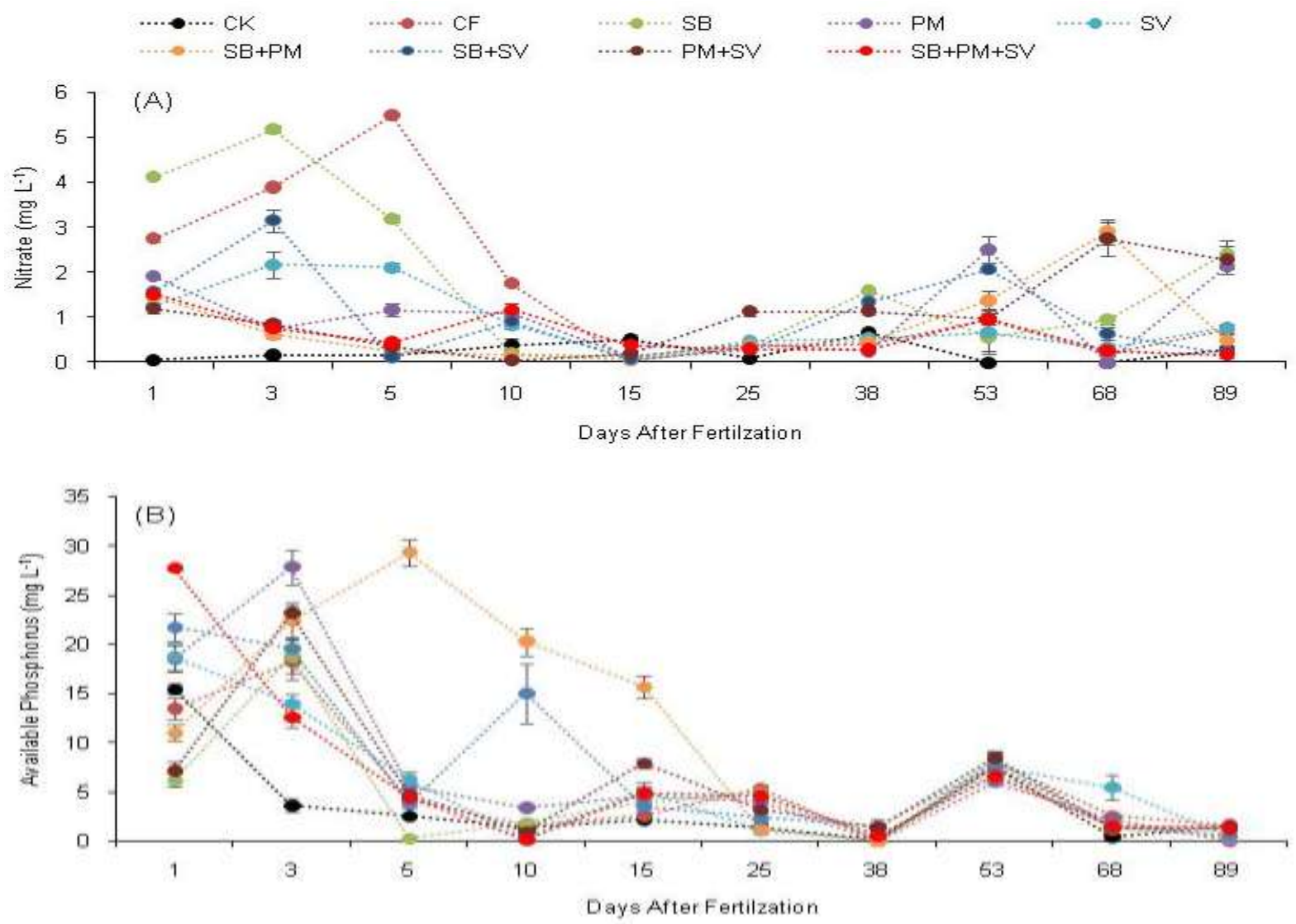

Figure 3. Nutrient concentration in field water (A) Nitrate (B) Available phosphorus. All the values are given as means \pm S.D.

The results of the current study indicate that the use of chemical fertilizers with industrial sugarcane by-products can improve the NUE, INE, HI, and NPFP significantly (Figure 2). The higher dose of chemical fertilizers results in reduced $\mathrm{N}$-use efficiency and increased $\mathrm{N}$ losses (Agegnehu et al., 2016). The highest NUE was observed in SB which might be due to its slow releasing capacity and at an appropriate time (Kalaivanan and Omar Hattab, 2016). SB and PM have sufficient capability to conserve $\mathrm{N}$ in their structural biomass, thus reduce its loss and improve its uptake (Meunchang et al., 2005), which could be the basic reason for improved NUE. Due to the production of oxalic acids during microbial decomposition of organic inputs, the $P$ efficiency could be increased significantly (Dotaniya et al., 2016). Studies showed that fertilizer use efficiency increases when organics are applied in combination with the mineral fertilizers (Agegnehu et al., 2016). It might be due to the change in soil surface properties, soil $\mathrm{P}$ status, and recycling of $\mathrm{P}$ (Mitran and Mani, 2017).
Field water analysis showed that integrated usage of organic amendments with chemical fertilization has reduced the nitrate concentration in-field water at the early rice growth stage (Figure 3a), which, reduces $\mathrm{N}$ losses, improves crop productivity, and nutrient use efficiency. The reason associated with less nitrate with organic amendments is ammonia immobilization enhancement and competition for nitrifiers, which prevents nitrate loss ((Wang et al., 2015). Chemical fertilization has abrupt release of $\mathrm{N}$; this results in $\mathrm{N}$ losses at early 15 days of fertilization. After excessive loss the availability is reduced at later on days, while organic byproducts help to maintain the $\mathrm{N}$ release throughout cropping duration. Hence, results in better production. The organics when applied increased the phosphorus availability at early stages (Figure $3 \mathrm{~b}$ ) because $\mathrm{P}$ mineralization stimulated due to the high microbial activity. At later stages, the organic inputs get reduced, which indicated low P mineralization (Garg and Bahl, 2008). The incorporation of organic byproducts might release organic acids, promote 
microbial activity, and stimulate the activity of phosphatase and dehydrogenase which results in improved $P$ solubilization (Garg and Bahl, 2008). Besides, the decomposition of organic inputs also releases nutrients such as $P$ (Amin, 2018). Overall, the nutrient concentration was high in CF at the early stages because the chemical fertilizers provide nutrients but later it reduced. However, puddling and fertilization might increase the risk of eutrophication (Leon and Kohyama, 2017). Additionally, organic inputs when combined with SB reduced environmental pollution due to its binding capacity ((Dotaniya et al., 2016). Results also indicate that higher $\mathrm{P}$ in surface water can act as a new source of water pollution, hence it might be concluded that all combinations are not good to use. While some of them have chances of to originate a new pollution generation in nearby water bodies.

The results indicate that the use of organics including SB, PM, or SB+PM along with inorganic fertilizers improves the farm income. The economic analysis includes the cost of labor, irrigation, rice seedling, fertilizer, and organic amendments. Some farmers use their resources such as labor, seedlings etc. to minimize the total cost. Our study concludes that low-cost organic inputs are a rich source of nutrients and improve the rice yield, nutrient uptake, and efficiency along with better farm income. The agriculture field is a safe way to dispose-off these industrial sugarcane byproducts. These organics are environment friendly and reduces the $\mathrm{N}$ and $\mathrm{P}$ losses as well. Moreover, it improves the farm income without increasing rates of chemical fertilizers.

The organic inputs can be obtained from the sugar industry and applied in the rice fields. The study also helps to enhance the socio-economic interactions between the agriculture and industrial sector. The combined use of these byproducts with optimum dose can provide an effective alternative for chemical fertilization and minimize the losses associated with it. The accurate dose of these organic amendments for specific crops and their effects on soil properties are still needed to be studied. The long-term effects of using these industrial sugarcane byproducts as organic fertilizers are also a research gap. A proper management strategy for maximizing the input use efficiencies and reducing the losses is needed to be introduced. Ammonia $\left(\mathrm{NH}_{3}\right)$ volatilization is also an aspect of $\mathrm{N}$ losses in alkaline soils, the study of such gas emissions and management with these by- products is also required. A study about the environmental impacts of organic inputs on eutrophication and global warming needs to be studied.

\section{CONCLUSION}

The results revealed that the use of sugar industry by-products is good for rice productivity, nutrient uptake and concentration as well as for farm income. The use of these by-products in rice production can help to minimize the problems associated with their storage, and also reduce environmental pollution. The use of SB improves the crop yield and is cheapest among others. The combined use of organics also improves nutrient concentrations in plants, reduced nutrient losses, and is also safe disposal of by-products. Future research is needed mainly focusing on finding the optimum dose of application, runoff and leaching losses, $\mathrm{NH}_{3}$ and nitrous oxide emission, and their longterm utilization impacts.

\section{ACKNOWLEDGMENT}

The by-products used in this study were provided by Faizan-Bin-Fazal (BG booster company, Bahawalpur, Pakistan). The authors would like to acknowledge their cooperation during the collection, handling, and transportation of the materials.

\section{CONFLICT OF INTEREST}

The authors declare that they have no known competing financial interests or personal relationships that could have appeared to influence the work reported in this paper.

\section{AUTHOR'S CONTRIBUTION}

Q. A. Raza: Conceptualization, methodology, software, formal analysis, investigation, writingoriginal draft preparation

M. A. Bashir: Conceptualization, methodology, software, formal analysis, investigation, writingoriginal draft preparation

A. Rehim: Conceptualization, methodology, validation, resources, writing-review and editing, supervision

M. Z. Hye: Methodology, validation, resources, writing-review and editing, supervision

Z. H. Tarar: Software, writing-review and editing, formal analysis

\section{REFERENCES}

Agegnehu, G., P. N. Nelson and M. I. Bird. 2016. The effects of biochar, compost and 
their mixture and nitrogen fertilizer on yield and nitrogen use efficiency of barley grown on a Nitisol in the highlands of Ethiopia. Science. Total Environment, 569: 869-879.

Bahadur, L., D. D. Tiwari, J. Mishra and B. R. Gupta. 2013. Nutrient management in ricewheat sequence under sodic soil. Journal of the Indian Society of Soil Science, 61 (4): 341-346.

Bashir, M. A., A. Rehim, J. Liu, M. Imran, H. Liu, M. Suleman and S. Naveed. 2019. Soil survey techniques determine nutrient status in soil profile and metal retention by calcium carbonate. Catena, 173: 141-149.

Bashir, M. A., H. Wang, J. Pan, B. Khoshnevisan, W. Sun, L. Zhai, X. Zhang, N. Wang, A. Rehim. and H. Liu. 2021. Variations in soil nutrient dynamics and their composition in rice under integrated ricecrab co-culture system. Journal of Cleaner Production, 281:125222.

Bashir, M. A., J. Liu, Y. Geng, H. Wang, J. Pan, D. Zhang, A. Rehim, M. Aon and H. Liu. 2020. Co-culture of rice and aquatic animals: An integrated system to achieve production and environmental sustainability. Journal of Cleaner Production, 249: 119310.

Cataldo, D. A., M. H. Haroon, L. E. Schrader and V. L. Youngs. 1975. Rapid colorimetric determination of nitrate in plant tissue by nitration of salicylic acid. Communications in Soil Science and Plant Analysis, 6 (1): 71-80.

Chen, D., L. Yuan, Y. Liu, J. Ji and H. Hou. 2017. Long-term application of manures plus chemical fertilizers sustained high rice yield and improved soil chemical and bacterial properties. European Journal of Agronomy, 90: 34-42.

Da Silva, A., R. Rossetto, J. Bombecini, M. Piemonte and T. Muraoka. 2014. Nitrogen mineralization from sugarcane vinasse. Journal of Plant Nutrition, 37 (8): 1227-1236.

Dotaniya, M. L., S. C. Datta, D. R. Biswas, C. K. Dotaniya, B. L. Meena, S. Rajendiran, K. L. Regar and M. Lata. 2016. Use of sugarcane industrial by-products for improving sugarcane productivity and soil health. International Journal of Recycling of Organic Waste in Agriculture, 5 (3): 185-194.

El-Eyuoon, A. and A. Z. Amin. 2018. Improvement in phosphorus use efficiency of corn crop by amending the soil with sulfur and farmyard manure. Soil and Environment, 37 (1): 62-67.

Garg, S. and G. S. Bahl. 2008. Phosphorus availability to maize as influenced by organic manures and fertilizer $P$ associated phosphatase activity in soils. Bioresource Technology, 99 (13): 5773-5777.

Gonfa, A., B. Bedadi and A. Argaw. 2018. Effect of bagasse ash and filter cake amendments on wheat (Triticum turgidum L.var. durum) yield and yield components in nitisol. International Journal of Recycling of Organic Waste in Agriculture, 7 (3): 231-240.

Hussain, A. 2013. Economic analysis of rice crop cultivation. Journal of Agriculture Research, 51 (2): 1-14.

Iqbal, S., C. Thierfelder, H. Z. Khan, H. M. R. Javeed, M. Arif and M. Shehzad. 2017. Maximizing maize quality, productivity and profitability through a combined use of compost and nitrogen fertilizer in a semi-arid environment in Pakistan. Nutrient Cycling in Agroecosystems, 107 (2): 197-213.

Jackson, M. L. 1960. Soil chemical analysis. Engleweed Cliff, New Jersy, 183-190.

Kalaivanan, D. and K. Omar Hattab. 2016. Recycling of sugarcane industries byproducts for preparation of enriched pressmud compost and its influence on growth and yield of rice (Oryza sativa L.). International Journal of Recycling of Organic Waste in Agriculture, 5 (3): 263-272.

Kjeldahl, J. 1883. Neue Methode zur Bestimmung des Stickstoffs in organischen Körpern. Zeitschrift für Analytische Chemie, 22: 366-382.

Ku, H. H., J. H. Ryu, H. S. Bae, C. Jeong and S. E. Lee. 2019. Modeling a long-term effect of rice straw incorporation on SOC content and grain yield in rice field. Archives of Agronomy and Soil Science, 65 (14): 1941-1954.

Leon, A. and K. Kohyama. 2017. Estimating nitrogen and phosphorus losses from lowland paddy rice fields during cropping seasons and its application for life cycle assessment. Journal of Cleaner Production, 164: 963-979..

Mahmood, F., I. Khan, U. Ashraf, T. Shahzad, S. Hussain, M. Shahid, M. Abid and S. Ullah. 2017. Effects of organic and inorganic manures on maize and their residual impact on soil physico-chemical properties. Journal of Soil Science and Plant Nutrition, 17 (1): 22-32.

McGeorge, W. T. 1954. Diagnosis and Improvement of Saline and Alkaline Soils. Soil Science Society of America Journal, 18.3: 348. 
Meunchang, S., S. Panichsakpatana and R. W. Weaver. 2005. Co-composting of filter cake and bagasse; by-products from a sugar mill. Bioresource Technology, 96 (4): 437-442.

Mitran, T. and P. K. Mani. 2017. Effect of organic amendments on rice yield trend, phosphorus use efficiency, uptake, and apparent balance in soil under long-term rice-wheat rotation. Journal of Plant Nutrition, 40 (9): 1312-1322.

Olsen, S. R., C. V Cole, F. Watandbe and L. Dean. 1954. Estimation of Available Phosphorus in Soil by Extraction with sodium Bicarbonate. Journal of Chemical Information and Modeling, 53:1689-1699.

Pakistan Bureau of Statistics. 2018. Agricultural Statistic of Pakistan. Minestry of Food, Agriculture and Livestock, Islamabad, Pakistan.

Pakistan Bureau of Statistics. 2019. Agricultural Statistic of Pakistan. Minestry of Food, Agriculture and Livestock, Islamabad, Pakistan.

Pandey, A., C. R. Soccol, P. Nigam and V. T. Soccol. 2000. Biotechnological potential of agro-industrial residues. I: Sugarcane bagasse. Bioresource Technology, 74 (1): 69-80.

Payá, J., J. Monzó, M. V. Borrachero, M. M. Tashima and L. Soriano. 2018. Bagasse ash waste and supplementary cementitious materials in concrete, 559-598.

Prado, R. D. M., G. Caione and C. N. S. Campos. 2013. Filter cake and vinasse as fertilizers contributing to conservation agriculture. Applied and Environmental Soil Science, (581984): 1-8.

Rangaraj, T., E. Somasundaram, M. M. Amanullah, V. Thirumurugan, S. Ramesh and S. Ravi. 2007. Effect of agro-industrial wastes on soil properties and yield of irrigated finger millet (Eleusine coracana L. Gaertn) in coastal soil. Research Journal of Agriculture and Biological Sciences, 3 (3): 153-156.

Rehman, S. U. 2019. Major nutrient fluxes and water use efficiency of winter vegetables under peri-urban farming of North-Western Punjab, Pakistan. Pakistan Journal of
Botany, 51 (5):1753-1759.

Reitemeier, R. F. 1963. Methods of Analysis for Soils, Plants, and Waters. Soil Science Society of America Journal, 27: IV.

Richards, L. A. 1954. Diagnosis and improving of saline and alkaline soils. US, Salinity Laboratory Staff. Agriculture. Handbook 60.

Sarwar, G., N. Hussain, H. Schmeisky, S. Suhammad, M. Ibrahim and S. Ahmad. 2008. Efficiency of various organic residues for enhancing rice-wheat production under normal soil conditions. Pakistan Journal of Botany, 40 (5): 2107-2113.

Soni, N., R. G. Leon, J. E. Erickson, J. A. Ferrell, M. L. Silveira and M. C. Giurcanu. 2014. Vinasse and Biochar Effects on Germination and Growth of Palmer Amaranth (Amaranthus palmeri), Sicklepod (Senna obtusifolia), and Southern Crabgrass (Digitaria ciliaris). Weed Technology, 28 (4): 694-702.

Walkley, A. 1947. A critical examination of a rapid method for determining organic carbon in soils-effect of variations in digestion conditions and of inorganic soil constituents. Soil Science, 63 (4): 251-264.

Wang, J., B. Zhu, J. Zhang, C. Müller and Z. Cai. 2015. Mechanisms of soil $N$ dynamics following long-term application of organic fertilizers to subtropical rain-fed purple soil in China. Soil Biology and Biochemistry, 91: 222-231.

Wei, W., Y. Yan, J. Cao, P. Christie, F. Zhang and M. Fan. 2016. Effects of combined application of organic amendments and fertilizers on crop yield and soil organic matter: An integrated analysis of long-term experiments. Agriculture, Ecosystems and Environment, 225: 86-92.

Yang, S. D., J. X. Liu, J. Wu, H. W. Tan and Y. R. Li. 2013. Effects of Vinasse and Press Mud Application on the Biological Properties of Soils and Productivity of Sugarcane. Sugar Tech, 15 (2): 152-158.

Zhang, M., Y. Yao, Y. Tian, K. Ceng, M. Zhao, M. Zhao and B. Yin. 2018. Increasing yield and $\mathrm{N}$ use efficiency with organic fertilizer in Chinese intensive rice cropping systems. Field Crops Research, 227: 102-109. 